\title{
Large and Medium-Sized Mammals of Carajás National Forest, Pará State, Brazil
}

\author{
Andréa Siqueira Carvalho ${ }^{1,3 *}$, Frederico Drumond Martins ${ }^{2}$, Francilma Mendes Dutra ${ }^{3}$, Donald \\ Gettinger ${ }^{4}$, Fernanda Martins-Hatano ${ }^{3}$ and Helena de Godoy Bergallo ${ }^{5}$ \\ 1 Universidade do Estado do Rio de Janeiro, Programa de Pós-Graduação em Ecologia e Evolução, Instituto de Biologia, Departamento de Ecologia, \\ Rua São Francisco Xavier 524, CEP 20559-900, Rio de Janeiro, RJ, Brasil. \\ 2 ICMBio-Instituto Chico Mendes de Conservação da Biodiversidade, Rua Guamá 23, 68516-000, Floresta Nacional de Carajás, Pará, Brasil. \\ 3 Universidade Federal Rural da Amazônia, Rua A, CEP 68515-000, Parauapebas, PA, Brasil. \\ 4 University of Nebraska-Lincoln, Harold W. Manter Laboratory of Parasitology, W529 Nebraska Hall, 68588-0514, Lincoln, Nebraska, U.S.A. \\ 5 Universidade do Estado do Rio de Janeiro, Instituto de Biologia, Departamento de Ecologia, Rua São Francisco Xavier 524, CEP 20559-900, Rio de \\ Janeiro, RJ, Brasil \\ * Corresponding author. E-mail: andreasicarvalho@hotmail.com
}

\begin{abstract}
The Carajás National Forest is located in the Amazonian region, Pará State, Brazil and is part of a mosaic of conservation units comprising over one million hectares. This region has been explored for its mineral reserves, but knowledge of the distribution of animals and plants is lacking. The objective of this paper is to provide a list of the medium and large-sized mammals recorded from the Carajás NF. We used four methods to record mammals: linear transects, camera traps, records of road-killed animals, and opportunistic observations. We recorded 45 species distributed in nine taxonomic orders, eight of them currently on the Brazilian list of threatened species and seven in the IUCN red list. The area has high mammalian diversity and holds $56 \%$ of the threatened species known for the State, confirming that the study area is correctly categorized as Extremely High Priority for the conservation of Brazilian biodiversity.
\end{abstract}

\section{INTRODUCTION}

Conservation units are effective barriers against the disturbance of occupation and destruction of natural habitats, which is an ever increasing alarming threat in Brazil (Silva 2005). In the Amazon region, conservation strategies have focused more on areas used by humans (reserves of sustainable use) than in uninhabited areas (complete protection) (Soares-Filho et al. 2006). The Carajás National Forest (Carajás NF - Figure 1) is part of a mosaic of conservation units covering more than one million hectares. The Conservation and Sustained Use of the Brazilian Biological Diversity Project (PROBIO) selected the entire mosaic as an area of high priority for the conservation of Brazilian biodiversity (MMA, 2003). Both, sustainable use and complete protection areas are found within this mosaic.

Some regions of Brazil, especially in the Amazon, present large gaps in scientific information. The southern part of Pará, including the Carajás NF is considered to be scientifically very poorly known (Paglia et al. 2008), despite being regarded as an area of high priority for conservation. The objective of this paper is to provide a list of the medium and large-sized mammals documented in the Carajás NF.

\section{MATERIALS AND MeThodS}

Study site

The Carajás NF is located in the northern region of Brazil, in the municipalities of Parauapebas, Canaã dos Carajás and Água Azul do Norte, in the State of Pará. It is situated between the geographic coordinates of $05^{\circ} 52^{\prime} 00^{\prime \prime}$ $-06^{\circ} 33^{\prime} 00^{\prime \prime} \mathrm{S}, 49^{\circ} 53^{\prime} 00^{\prime \prime}-50^{\circ} 45^{\prime} 00^{\prime \prime} \mathrm{W}$.
This conservation unit is bordered by three other protected areas; on the west by the Cateté Xikrin Indian Reserve, on the north by the Igarapé Gelado Environmental Protection Area, and on the northwest by the TapirapéAquiri National Forest (Figure 1).

The study was carried out in the Northern Massif (Serra Norte) of the Carajás NF, where the highest altitudes reach $750 \mathrm{~m}$. More than $95 \%$ of this conservation unit is covered by forest and the remaining 3\% corresponds to a shorter vegetation type of low biomass on rocky plateaus. This vegetation grows where the soil is rich in iron and is known as "metaphilic savannah" (Figure 2), "rocky grassland", "metaphilic vegetation" or simply "canga vegetation" (Secco and Mesquita 1983; Silva 1986; Porto and Silva 1989; Silva 1992; Cleef and Silva 1994; Silva et al. 1996). Canga is a rock stratum of hematite with high concentrations of iron that serves as the soil base for this vegetation. Nine distinctly different plateaus are known in the Northern Mountain Range of the Carajás NF (hereafter N1 to N9).

\section{Data Collection}

There is an enormous variation in body size, life histories and habitat preferences within medium and large mammals. For this reason, the research and inventory of them requires the use of more than a single methodology (Voss and Emmons 1996). Four distinct methodologies were used to prepare this list of species (IBAMA collecting license 09-B/2009 - MAB/Fauna).

The linear transect and camera-trap methodologies were carried out during the same study, in four areas located in the interior of the Carajás NF, two covered by 
old-growth forest and two with metaphilic savannah (located in N2 and N4). One old-growth-forest area and N4 savannah are located in areas adjacent to an iron ore mine. The mined areas are approximately $7.2 \mathrm{~km}$ from areas not mined.

The study was carried out from October 2008 to July 2010. Recording effort consisted of 66 days of linear transects and 241 days of camera trapping.

\section{Linear Transects}

Three of the four areas had five linear transects, each approximately 1200 -meters long, parallel and distant 300 meters from each other. The fourth area, of metaphilic savannah, had only four transects because of its slightly smaller size. Each transect was sequentially marked and geo-referenced every $20 \mathrm{~m}$, so that all records would have a precise geographic coordinate.

Four sampling periods were carried out in each area, resulting in approximately $24 \mathrm{~km}$ of linear transects. The transects were walked in alternating diurnal (6:0010:00) and crepuscular sampling periods (14:00-18:00). Approximately $4 \mathrm{~km}$ were walked during each sampling period (average speed of $1 \mathrm{~km} / \mathrm{h}$ ) each day, and we attempted to maintain an equal sampling effort among transects. During transect surveys, recordings were made of visual sightings and other signs (vocalizations, footprints, burrows and skeletal remains). Mammal species recorded by signs were identified following Borges and Tomás (2004) and Mamede and Alho (2008).

\section{Camera traps}

Twenty-five camera-trap sites were distributed in five transects in each of the study areas. The camera traps were set along the transects, with a minimum of $300 \mathrm{~m}$ between traps, giving an equal sampling effort for each of the four study areas.

A total of 50 camera traps (Tigrinus $\AA$, model 6.0) with Sony 10.1 mega-pixel digital cameras were used simultaneously in two study areas. In most cases, the mode program "prog1f" was used in forested habitats, and mode program "prog2f" was used in metaphilic savannah habitats, which are the programs recommendations for closed and open areas, respectively.

\section{Road kills}

The road kill data was collected from December 2008 to April 2010. The data was initially collected for another project and was used in this survey to complement the list of medium and large mammal species. Animals were collected from a vehicle that traversed a total of $286 \mathrm{~km}$ every day along the Raymundo Mascarenhas Highway, the main road accessing the interior region of the Carajás NF. Surveys were conducted twice a day (morning and evening) continuously, including weekdays and holidays.

\section{Opportunistic observations}

During field work, opportunistic observations from camera-trapping and direct observation (with photos whenever possible) were made in the Carajás NF. Each

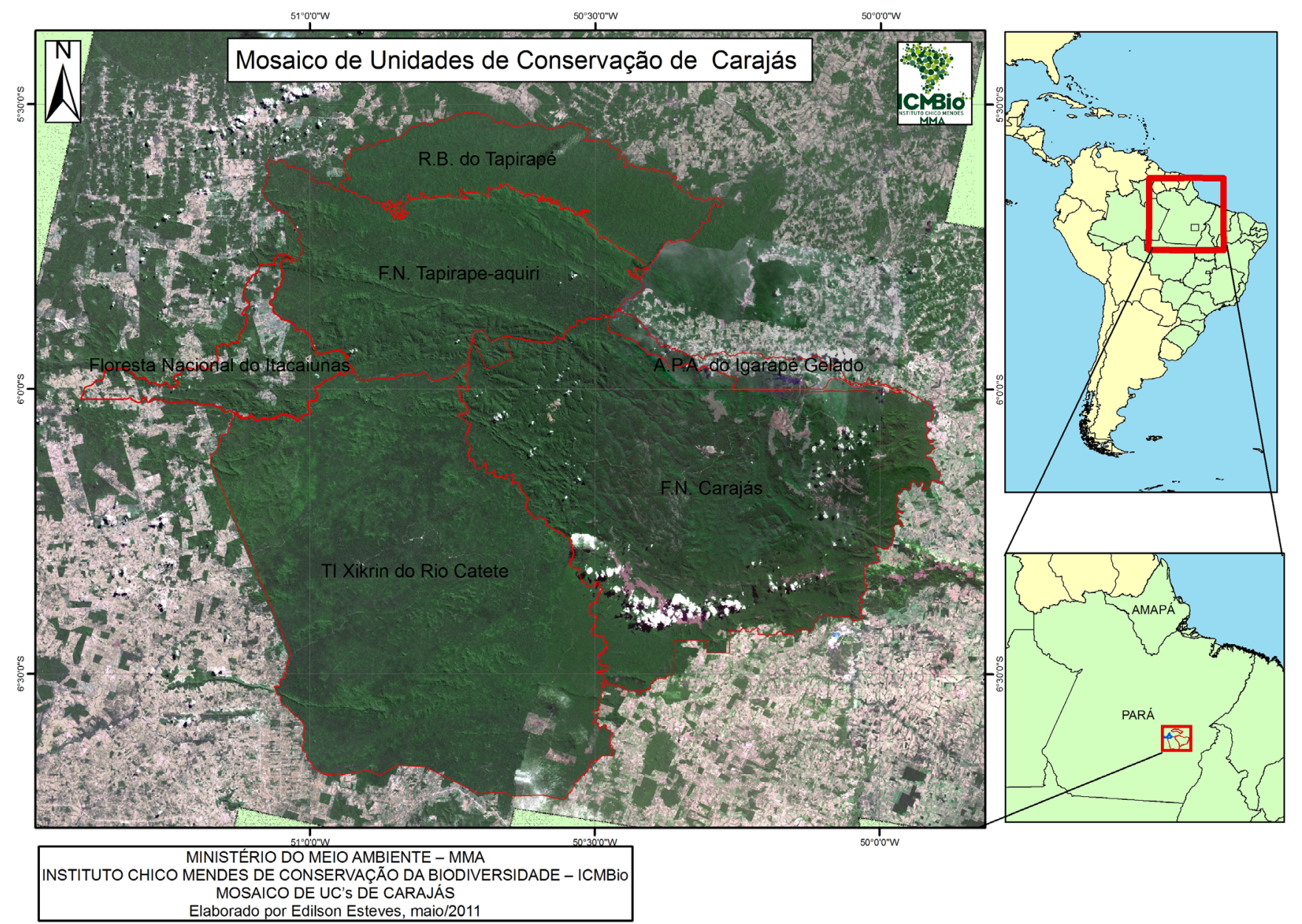

FIGURE 1. Map showing the location of the area of study in Brazil and in detail within Pará state, the location of the mosaic of Conservation Units including the Carajás National Forest. Source: Project to Survey and Monitor the Fauna of the Carajás National Forest. 
sampling point for these opportunistic records was georeferenced. Two river surveys were also carried out: one along the Parauapebas River and one on the Itacaiúnas River. The Itacaiúnas River (Figure 3), which forms the border with the Tapirapé-Aquiri National Forest, was sampled continuously along $99.77 \mathrm{~km}$ (including the return trip), with short breaks for resting and eating. The Parauapebas River, which separates the Carajás NF from the urban and rural regions of the municipality of Parauapebas, was traversed for $50 \mathrm{~km}$ using the same method.

Aiming to complement the methodology of "opportunistic observations" we aggregated information collected by ICMBio (Federal Agency responsible for managing the protect areas) for the presence of mammalian species. Between 2008 and 2010, during the reserve management activities such as monitoring, environment education and licensing inspection, any evidence of mammals of medium and large size was recorded.

Species names followed Wilson and Reeder (2005). Identification of species was based on illustrations and photographs available in the specialized literature (e.g. Eisenberg and Redford 1999; Reis et al. 2006; Bonvicino et al. 2008), always taking into consideration the regional distribution of specious taxa. Whenever doubts were raised, species identity was confirmed, through photos, by specialists.

The rarefaction curve of mammals species (transects and camera-traps) was created in the software EstimateS 8.0.0 (Colwell 2006) with 1000 randomizations and the firstorder jackknife (Jackknife 1) estimator.

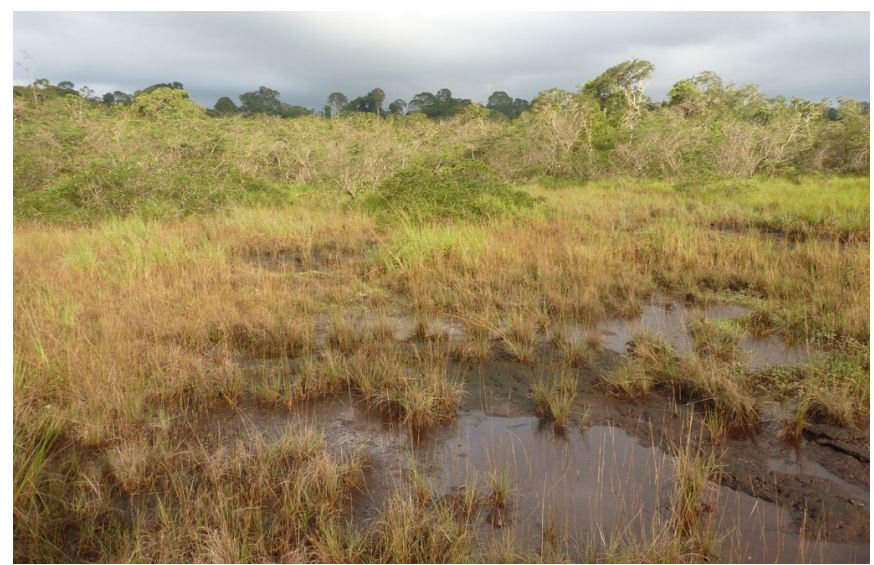

FiguRE 2. Area of metaphilic savannah in Carajás National Forest.

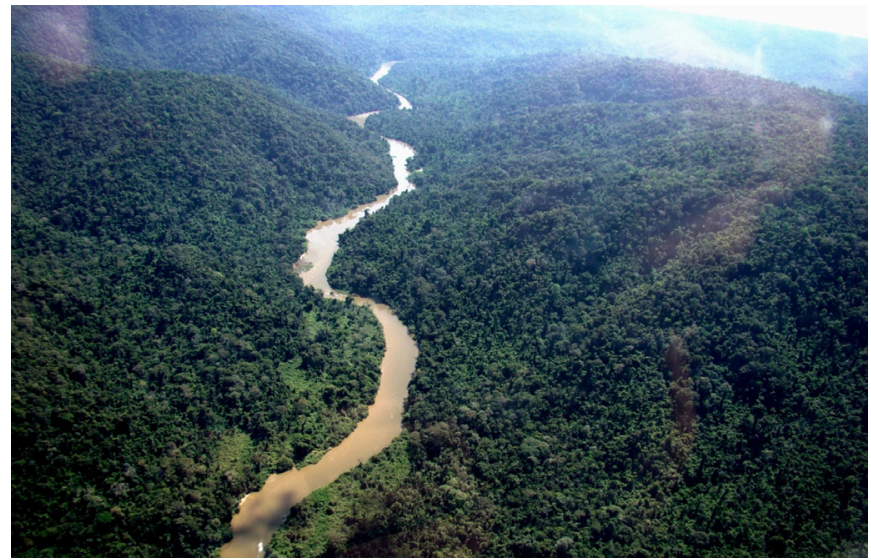

FIgURE 3. Itacaiúnas River, border of the Carajás and Tapirapé-Aquirí National Forest.

\section{RESULTS AND DISCUSSION}

A total of $432 \mathrm{~km}$ of transects were walked and 3,572 camera-traps*day were set in the four study areas. In both methods, the rarefaction curve tended to stabilize and plotted values for Jackknife 1 estimator were higher than the species richness observed (Figure 4).

Adding the records obtained by opportunistic observations, road kills, transect and camera-traps a total of 45 species of medium and large-sized mammals were registered (Figures 5-8). The use of four distinct methodologies was extremely important in producing our results and in verifying the presence of the different taxa of mammals.

The recorded species belong to nine orders: 15 species of Carnivora, six of Primates, five of Cingulata, seven of Rodentia, four of Artiodactyla, five of Pilosa, one of Lagomorpha, one of Perissodactyla one of Didelphimorphia (Table 1). For the last six orders cited, we registered all of the species of large and medium-sized mammals of probable occurrence in the southeastern region of Pará, listed in Reis et al. (2006). For Primates, all of the locally distributed species with diurnal habits were registered in this study (only Aotus sp. was not recorded, but it is a nocturnal species).

This study complements two surveys made previously in the area. Using only capture and direct observations, Toledo et al. (1999) recorded nine species (all included in this survey), which corresponds to $20 \%$ of the present list. The Management Plan for the Carajás NF (2003)
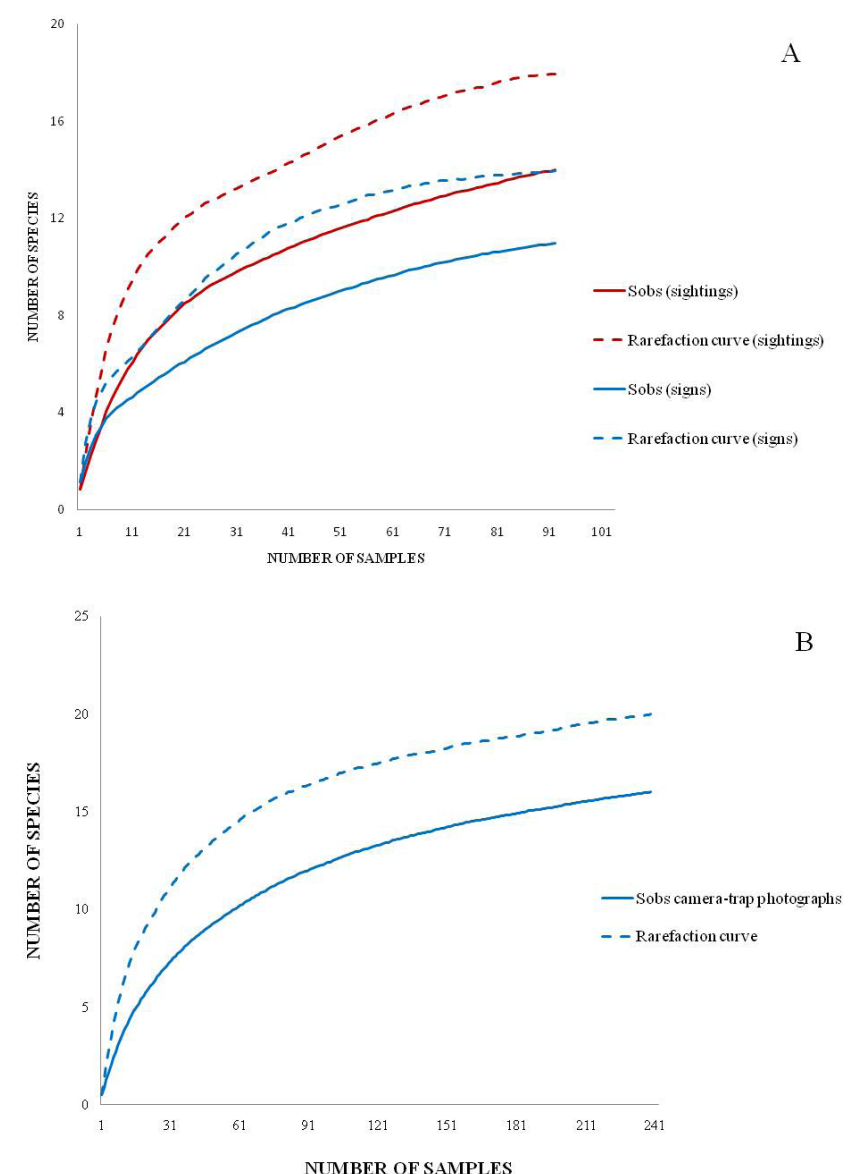

FIGURE 4. The rarefaction curve of large and medium sized mammals of Carajás National Forest, Pará State for linear transects (A) and Cameratrap days (B). Sobs is the total number of species observed in a sample and rarefaction curve is the estimated number of species (Jackknife 1). 
presented a list containing 21 species of medium and large-sized mammals, of which only one species, Mazama rufina, is not on our list. This deer, nevertheless, is not supposed to occur in Brazil. It is restricted to the Andes of Colombia, Ecuador and Peru (Eisenberg and Redford, 1999; Lizcano and Alvarez, 2008). Most probably, it was a misidentification.

Our list presents 19 new records for the Carajás National Forest (Table 1). In Pará, 15 species of mammals are listed as Species Threatened with Extinction, of which nine are terrestrial/arboreal. Of those, six occur in the Carajás NF, or $56 \%$ of the threatened species (SECTAM 2006). These are: Panthera onca, Puma concolor, Pteronura brasiliensis, Priodontes maximus, Myrmecophaga tridactyla and Chiropotes utahickae. Eight species on the Brazilian list of threatened species (Machado et al. 2008) occur in the area of study. These include the same species listed above (except P. concolor), plus Speothos venaticus, Leopardus
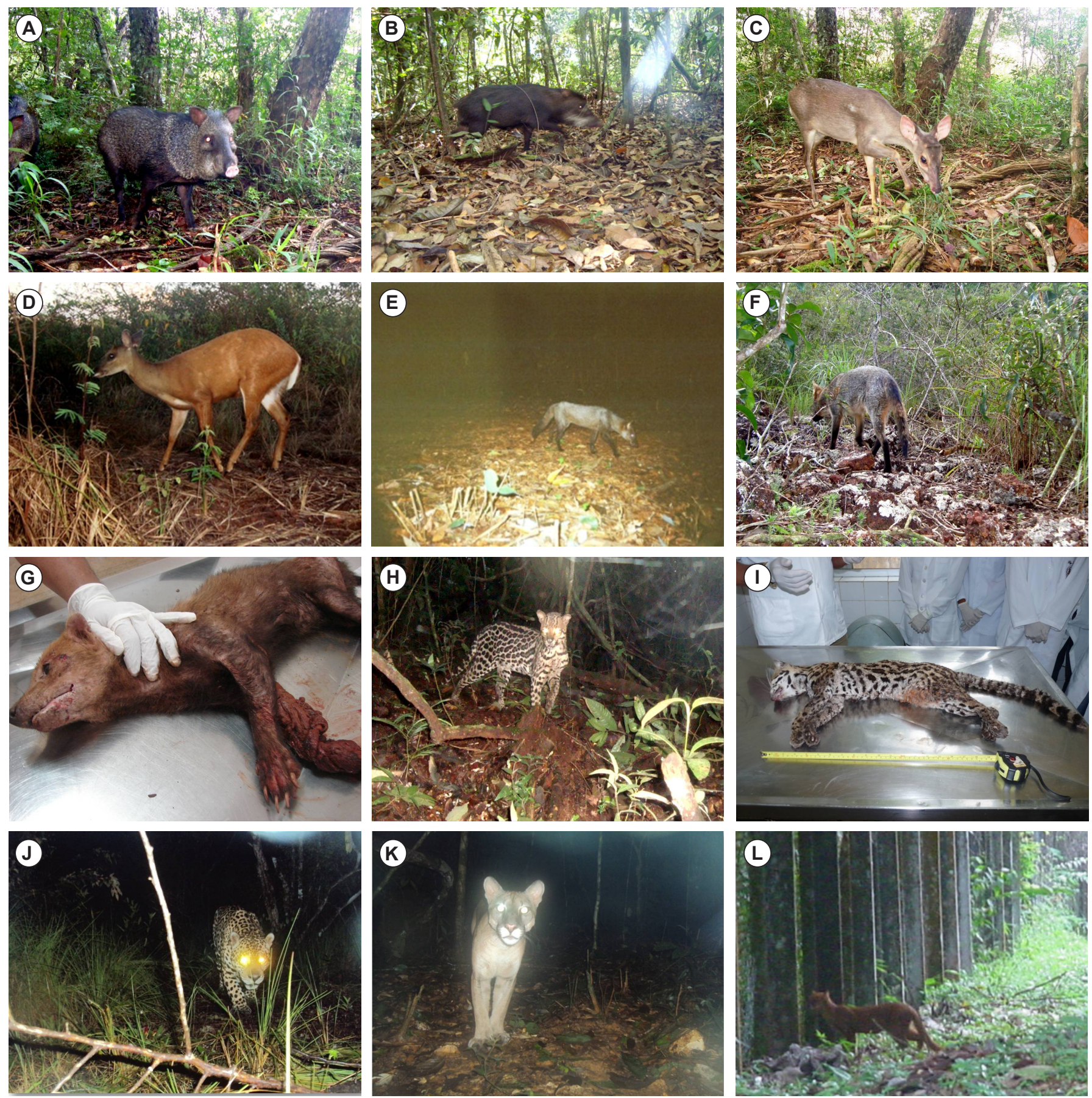

FIGURE 5. Mammals at the Carajás National Forest photographed. A) Pecari tajacu C2; I1; R1; L1. B) Tayassu pecari C2; I1; R1; L3. C) Mazama nemorivaga C2; I4; R1; L1. D) Mazama americana C2; I4; R1; L2. E) Atelocynus microtis C3; I5; R2; L12. F) Cerdocyon thous C2; I1; R1; L1. G) Speothos venaticus C5; I1; R6; L8. H) Leopardus pardalis C2; I1; R1; L3. I) Leopardus wiedii C2; I6; R5; L10. J) Panthera onca C2; I1; R1; L1. K) Puma concolor C2; I1; R1; L1. L) Puma yagouaroundi C8; I1; R4; L7.

C- Picture Credits: 1. A. Castilho; 2. A. Carvalho; 3. Arquivo ICMBio; 4. E. Pascoalini; 5. E. Perini; 6. F.D. Martins; 7. J.M. Rosa; 8. D. Santos. I- Identifier (photo analisys): 1. A. Carvalho; 2. G.-I. Ximenes; 3. L. Ávilla; 4. M. Barbanti; 5. R. Pitman and T. Oliveira; 6. R. Boulhosa; 7. L. Veiga. R- Kind of Record: 1. Camera trap in the transectes; 2. Camera traps out of the transectes (oportunistic observations); 3 . Visual sightings in the transectes; 4 . Visual sightings out of the transectes (oportunistic observations); 5. Road kill in the studied road; 6. Road kill out of the studied road (oportunistic observations). LLocality in the National Forest: 1. Savana N2; 2. Savana N4; 3. Forest N2; 4. Forest N4; 5. Itacaiúnas River; 6. Border with Gelado River Protect Area; 7. Urban Village; 8. Bahia River Project; 9. Sossego River; 10. Raymundo Mascarenhas road; 11. Forest N5; 12. Border with the Tapirapé-Aquirí National Forest. 
pardalis and L. wiedii. Seven listed as threatened by the IUCN (International Union for Conservation of Nature) occur in the study area - Atelocynus microtis, Pteronura brasiliensis, Tapirus terrestris, Priodontes maximus, Alouatta belzebul, Saguinus niger and Chiropotes utahickae.

The diversity of mammals of medium and large size found in the Carajás NF is quite high when compared to other protected areas in the Amazon. In Gurupi Biological Reserve, located in eastern Amazon, Maranhão State,
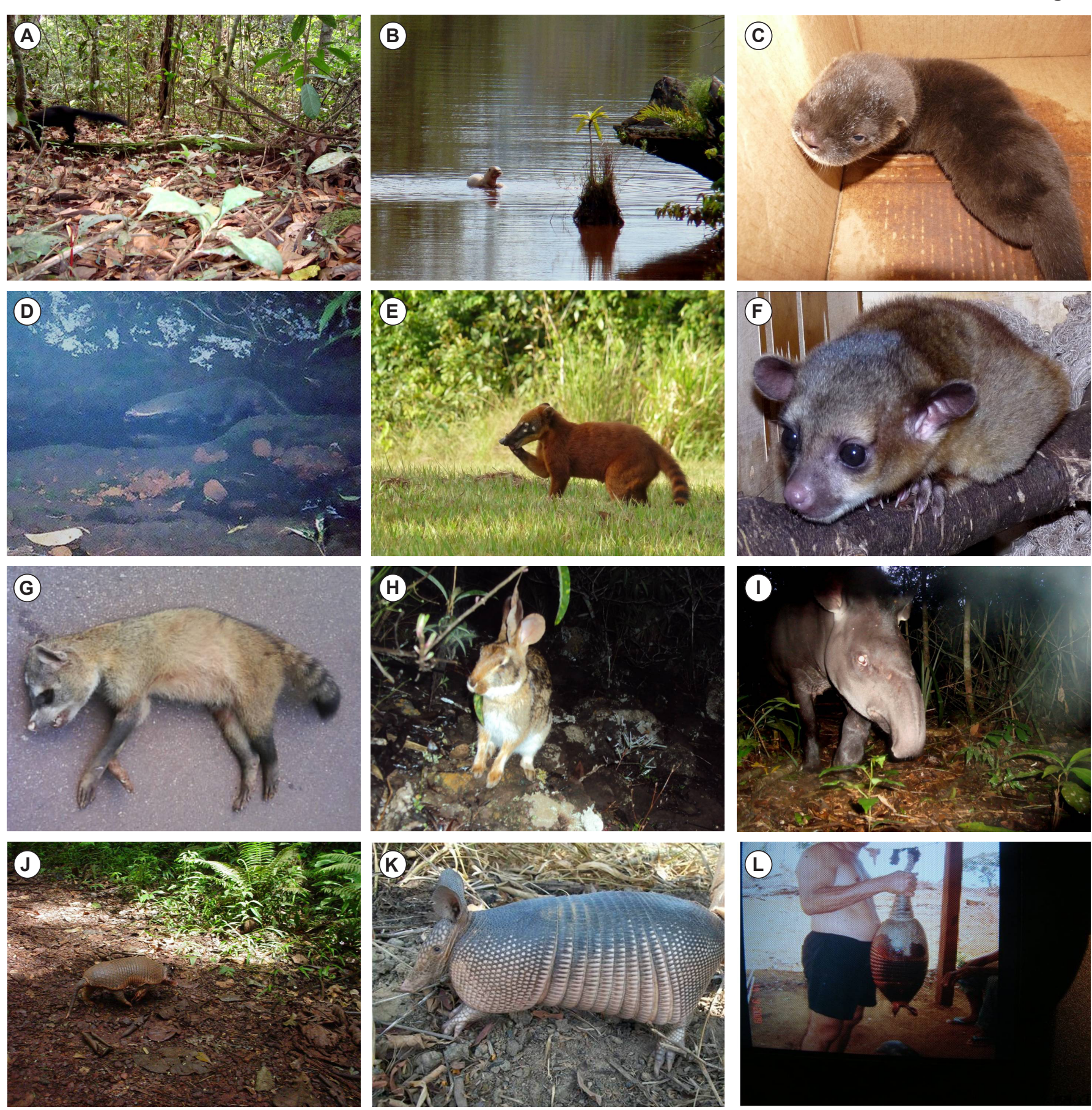

FiguRE 6. Mammals at the Carajás National Forest photographed. A) Eira barbara C2; I1; R1; L4. B) Pteronura brasiliensis C6; I6; R4; L6. C) Lontra longicaudis C2; I1; R4; L5. D) Galictis vittata C3; I1; R2; L8. E) Nasua nasua C2; I1; R4; L7. F) Potos flavus C2; I1; R4; L7. G) Procyon cancrivorus C2; I1; R5; L10. H) Sylvilagus brasiliensis C2; I1; R1; L2. I) Tapirus terrestri C2; I1; R1; L3. J) Cabassous unicinctus C4; I3; R4; L11. K) Dasypus novemcinctus C3; I3; R4; L11. L) Dasypus kappleri C3; I3; R4; L5.

C- Picture Credits: 1. A. Castilho; 2. A. Carvalho; 3. Arquivo ICMBio; 4. E. Pascoalini; 5. E. Perini; 6. F.D. Martins; 7. J.M. Rosa; 8. D. Santos. I- Identifier (photo analisys): 1. A. Carvalho; 2. G.-I. Ximenes; 3. L. Avilla; 4. M. Barbanti; 5. R. Pitman and T. Oliveira; 6. R. Boulhosa; 7. L. Veiga. R- Kind of Record: 1. Camera trap in the transectes; 2. Camera traps out of the transectes (oportunistic observations); 3. Visual sightings in the transectes; 4 . Visual sightings out of the transectes (oportunistic observations); 5. Road kill in the studied road; 6. Road kill out of the studied road (oportunistic observations). LLocality in the National Forest: 1. Savana N2; 2. Savana N4; 3. Forest N2; 4. Forest N4; 5. Itacaiúnas River; 6. Border with Gelado River Protect Area; 7. Urban Village; 8. Bahia River Project; 9. Sossego River; 10. Raymundo Mascarenhas road; 11. Forest N5; 12. Border with the Tapirapé-Aquirí National Forest. 
area of about 514,000 ha found a total of 41 mammalian species of medium and large size (Santos and MendesOliveira 2012). Iwanaga (2004) sampled 42 species to the Jau National Park, whereas Haugaasen and Peres (2007) recorded 27 species in Lake Uauaçú, in the Purus River. Patton et al. (2000) studied several areas along the river Juruá, and recorded 18 species in the lower portion of the river, 21 species in the central portion (both located in the state of Amazonas), and 28 species in the headwaters of the river, in the state of Acre.

Among all the published inventories of large and medium-sized mammals of the Brazilian Amazon, the present study was the one with the highest number of species. It is worth noting that our results are probably related to the fact that four complementary methodologies were used (transect census, camera-trapping, road-killing inventory and opportunistic records) and not necessarily that Carajás NF has a greater medium-large mammal
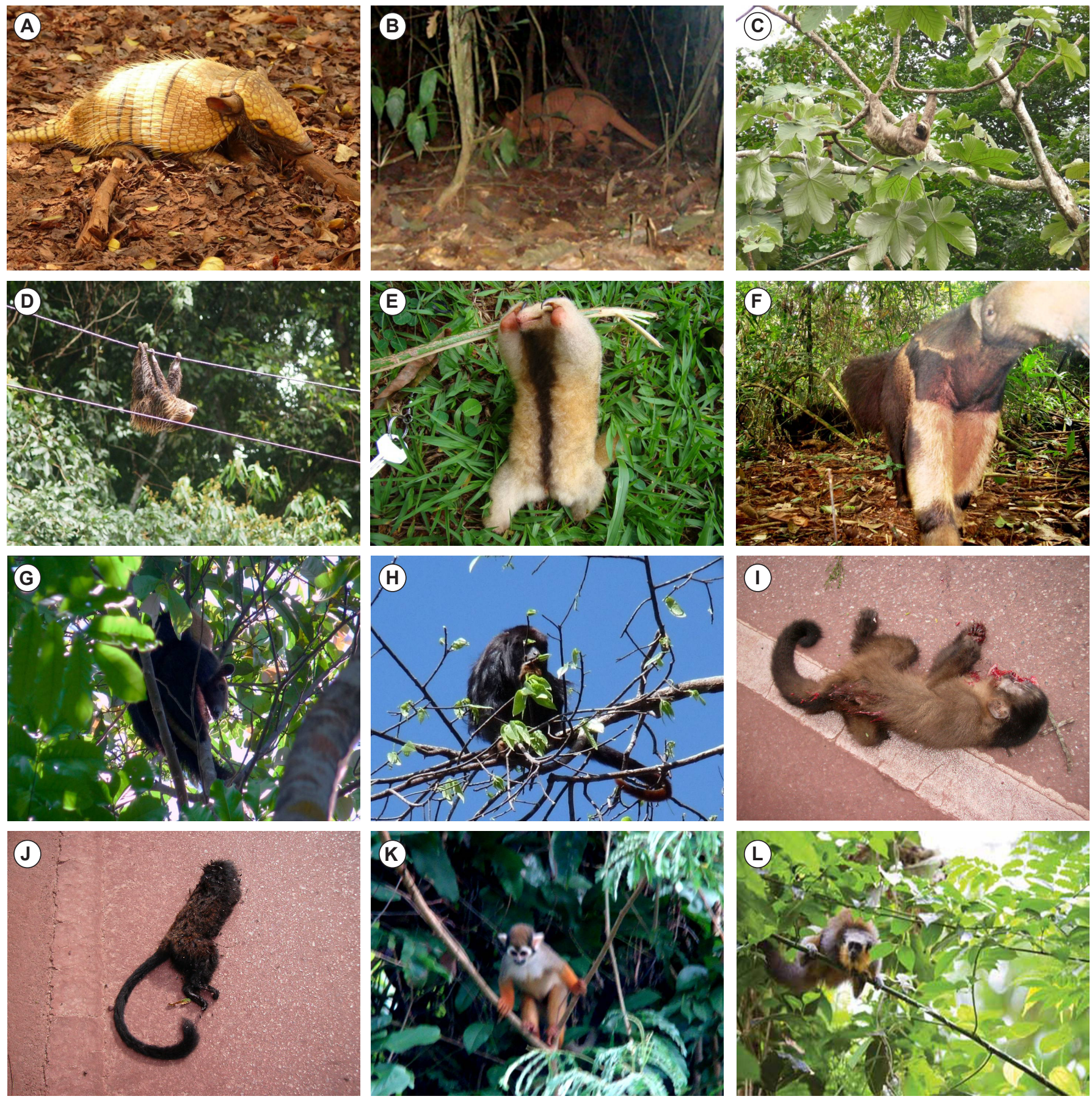

Figure 7. Mammals at the Carajás National Forest photographed. A) Euphractus sexcinctus C2; I3; R4; L7. B) Priodontes maximus C2; I3; R1; L3. C) Bradypus variegatus C2; I1; R4; L11. D) Choloepus didactylus C1; I1; R4; L11. E) Cyclopes didactylus C6; I1; R4; L11. F) Myrmecophaga tridactyla C2; I1; R2; L6. G) Tamandua tetradactyla C2; I1; R3; L1. H) Alouatta belzebul C2; I1; R3; L3. I) Sapajus apella C2; I1; R5; L10. J) Saguinus Níger C2; I1; R5; L10. K) Saimiri sciureus C7; I1; R4; L5. L) Callicebus moloch C7; I1; R4; L5.

C- Picture Credits: 1. A. Castilho; 2. A. Carvalho; 3. Arquivo ICMBio; 4. E. Pascoalini; 5. E. Perini; 6. F.D. Martins; 7. J.M. Rosa; 8. D. Santos. I- Identifier (photo analisys): 1. A. Carvalho; 2. G.-I. Ximenes; 3. L. Âvilla; 4. M. Barbanti; 5. R. Pitman and T. Oliveira; 6. R. Boulhosa; 7. L. Veiga. R- Kind of Record: 1. Camera trap in the transectes; 2. Camera traps out of the transectes (oportunistic observations); 3 . Visual sightings in the transectes; 4 . Visual sightings out of the transectes (oportunistic observations); 5. Road kill in the studied road; 6. Road kill out of the studied road (oportunistic observations). LLocality in the National Forest: 1. Savana N2; 2. Savana N4; 3. Forest N2; 4. Forest N4; 5. Itacaiúnas River; 6. Border with Gelado River Protect Area; 7. Urban Village; 8. Bahia River Project; 9. Sossego River; 10. Raymundo Mascarenhas road; 11. Forest N5; 12. Border with the Tapirapé-Aquirí National Forest. 
richness than other Amazonian regions. The area's species richness associated with the number of threatened species present highlights Carajás NF as a priority area for biodiversity conservation in Brazil. The area was formerly considered of an Extremely High Priority for biodiversity conservation by the Brazilian government (Brasília 2004).
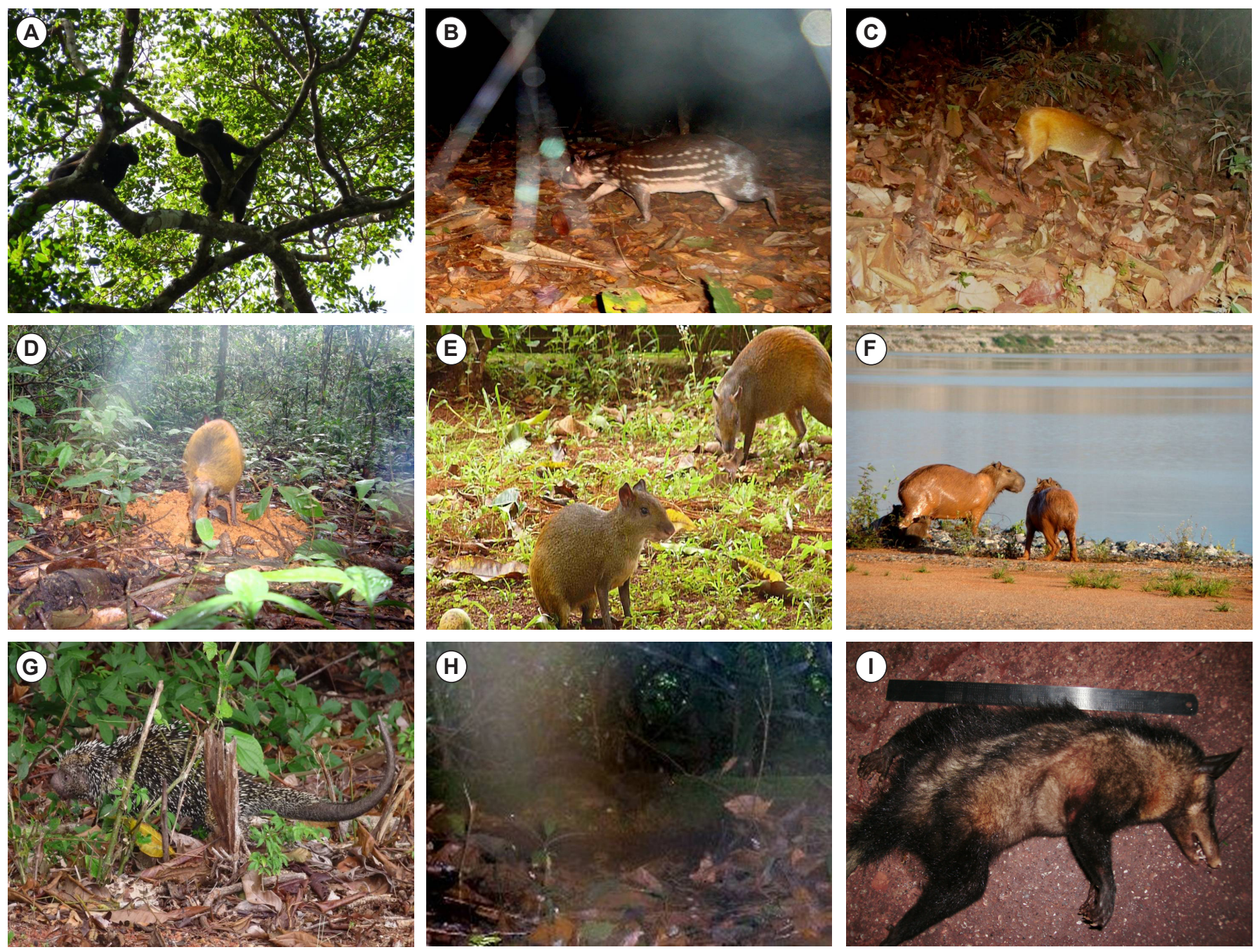

FiguRE 8. Mammals at the Carajás National Forest photographed. A) Chiropotes utahickae C2; I7; R3; L3. B) Cuniculus paca C2; I1; R1; L3. C) Dasyprocta croconota C2; I2; R1; L4. D) Dasyprocta prymnolopha C2; I2; R1; L3. E) Dasyprocta leporina C2; I2; R4; L7. F) Hydrochoerus hydrochaeris C6; I1; R4; L9. G) Coendou prehensilis C2; I1; R4; L7. H) Guerlinguetus gilvigulares C2; I1; R2; L8. I) Didelphis marsupialis C2; I1; R5; L10.

C- Picture Credits: 1. A. Castilho; 2. A. Carvalho; 3. Arquivo ICMBio; 4. E. Pascoalini; 5. E. Perini; 6. F.D. Martins; 7. J.M. Rosa; 8. D. Santos. I- Identifier (photo analisys): 1. A. Carvalho; 2. G.-I. Ximenes; 3. L. Avilla; 4. M. Barbanti; 5. R. Pitman and T. Oliveira; 6. R. Boulhosa; 7. L. Veiga. R- Kind of Record: 1. Camera trap in the transectes; 2. Camera traps out of the transectes (oportunistic observations); 3 . Visual sightings in the transectes; 4 . Visual sightings out of the transectes (oportunistic observations); 5. Road kill in the studied road; 6. Road kill out of the studied road (oportunistic observations). LLocality in the National Forest: 1. Savana N2; 2. Savana N4; 3. Forest N2; 4. Forest N4; 5. Itacaiúnas River; 6. Border with Gelado River Protect Area; 7. Urban Village; 8. Bahia River Project; 9. Sossego River; 10. Raymundo Mascarenhas road; 11. Forest N5; 12. Border with the Tapirapé-Aquirí National Forest.

TABLE 1. Large and medium-sized mammals of the Carajás National Forest. The codes used to designate the methodologies are: LT (line transect), CT (camera-trap photographs taken on study area transects), RK (road killed) and 00 (opportunistic observations). The codes designating the status of threat follow the nomenclature of the IUCN and were LC (Least Concern), NT (Near Threatened), DD (Data Deficient), VU (Vulnerable) e EN (Endangered). *(New records for the Carajás National Forest).

\begin{tabular}{|c|c|c|c|c|c|}
\hline \multirow{2}{*}{ TAXON } & \multirow{2}{*}{ COMMON NAME (in portuguese) } & \multirow{2}{*}{ METODOLOGIES } & \multicolumn{3}{|c|}{ THREAT } \\
\hline & & & $\mathbf{P A}$ & BR & IUCN \\
\hline \multicolumn{6}{|l|}{ ARTIODACTYLA } \\
\hline \multicolumn{6}{|l|}{ Tayassuidae } \\
\hline Pecari tajacu (Linnaeus, 1758) & Caititu & LT, CT & - & - & LC \\
\hline Tayassu pecari (Link, 1795) & Queixada & CT, 00 & - & - & NT \\
\hline \multicolumn{6}{|l|}{ Cervidae } \\
\hline Mazama americana (Erxleben, 1777) & Veado mateiro & LT, CT, RK, OO & - & - & DD \\
\hline Mazama nemorivaga* (Cuvier, 1817) & Veado fuboca & LT, CT & - & - & LC \\
\hline \multicolumn{6}{|l|}{ CARNIVORA } \\
\hline \multicolumn{6}{|l|}{ Canidae } \\
\hline Atelocynus microtis* & Cachorro-do-mato-de-orelha-curta & 00 & - & - & NT \\
\hline Cerdocyon thous (Linnaeus, 1766) & Raposinha & LT, CT, RK, OO & - & - & $\mathrm{LC}$ \\
\hline Speothos venaticus* (Lund, 1842) & Cachorro-vinagre & $\mathrm{CT}, \mathrm{OO}$ & - & VU & NT \\
\hline
\end{tabular}




\begin{tabular}{|c|c|c|c|c|c|}
\hline \multirow{2}{*}{ TAXON } & \multirow{2}{*}{ COMMON NAME (in portuguese) } & \multirow{2}{*}{ METODOLOGIES } & \multicolumn{3}{|c|}{ THREAT } \\
\hline & & & PA & BR & IUCN \\
\hline \multicolumn{6}{|l|}{ Felidae } \\
\hline Leopardus pardalis (Linnaeus, 1758) & Gato-maracajá-açu, Jaguatirica & LT, CT, RK & - & VU & LC \\
\hline Leopardus wiedii (Schinz, 1821) & Gato maracajá & RK & - & VU & NT \\
\hline Panthera onca (Linnaeus, 1758) & Onça pintada & LT, CT, RK, OO & VU & VU & NT \\
\hline Puma concolor (Linnaeus, 1771) & Suçuarana & LT, CT, RK & VU & - & LC \\
\hline Puma yagouaroundi (É. Geoffroy Saint-Hilare, 1803) & Gato-mourisco & 00 & - & - & $\mathrm{LC}$ \\
\hline \multicolumn{6}{|l|}{ Mustelidae } \\
\hline Eira barbara* (Linnaeus, 1758) & Papa-mel & CT, RK & - & - & LC \\
\hline Pteronura brasiliensis*(Gmelin, 1788) & Ariranha & 00 & VU & VU & EM \\
\hline Lontra longicaudis* (Olfers, 1818) & Lontra & 00 & - & - & DD \\
\hline Galictis vittata* $($ Schreber, 1766) & Furão & 00 & - & - & LC \\
\hline \multicolumn{6}{|l|}{ Procyonidae } \\
\hline Nasua nasua* (Linnaeus, 1766) & Quati & LT, CT, RK, OO & - & - & $\mathrm{LC}$ \\
\hline Potos flavus* (Schreber, 1774) & Jupará & $\mathrm{RK}, \mathrm{OO}$ & - & - & LC \\
\hline Procyon cancrivorus (G.[Baron] Cuvier, 1798) & Mão-pelada & RK & - & - & $\mathrm{LC}$ \\
\hline \multicolumn{6}{|l|}{ LAGOMORPHA } \\
\hline \multicolumn{6}{|l|}{ Leporidae } \\
\hline Sylvilagus brasiliensis (Linnaeus, 1758) & Tapeti & LT, CT, RK, OO & - & - & $\mathrm{LC}$ \\
\hline \multicolumn{6}{|l|}{ PERISSODACTYLA } \\
\hline \multicolumn{6}{|l|}{ Tapiridae } \\
\hline Tapirus terrestris Linnaeus, 1758 & Anta & LT, CT, RK, OO & - & - & VU \\
\hline \multicolumn{6}{|l|}{ CINGULATA } \\
\hline \multicolumn{6}{|l|}{ Dasypodidae } \\
\hline Cabassous unicinctus* (Linnaeus, 1758) & Tatu-rabo-mole & RK, $\mathrm{OO}$ & - & - & $\mathrm{LC}$ \\
\hline Dasypus novemcinctus* Linnaeus, 1758 & Tatu, Tatu-galinha & RK & - & - & LC \\
\hline Dasypus kappleri* Kraus, 1862 & Tatu-quinze-quilos & 00 & - & - & $\mathrm{LC}$ \\
\hline Euphractus sexcinctus* (Linnaeus, 1758) & Tatu-peba & 00 & - & - & LC \\
\hline Priodontes maximus* (Kerr,1792) & Tatu-canastra & LT, CT, OO & VU & VU & VU \\
\hline \multicolumn{6}{|l|}{ PILOSA } \\
\hline \multicolumn{6}{|l|}{ Bradypodidae } \\
\hline Bradypus variegatus Schinz, 1825 & Preguiça & 00 & - & - & $\mathrm{LC}$ \\
\hline Megalonychidae & & & & & \\
\hline Choloepus didactylus (Linnaeus, 1758) & Preguiça-real & RK, 00 & - & - & LC \\
\hline Myrmecophagidae & & & & & \\
\hline Cyclopes didactylus (Linnaeus, 1758) & Tamanduaí & $\mathrm{RK}, \mathrm{OO}$ & - & - & LC \\
\hline Myrmecophaga tridactyla* (Linnaeus, 1758 ) & Tamanduá-bandeira & $\mathrm{RK}, \mathrm{OO}$ & VU & VU & NT \\
\hline Tamandua tetradactyla* (Linnaeus, 1758) & Mambira & LT, RK, OO & - & - & LC \\
\hline PRIMATES & & & & & \\
\hline Atelidae & & & & & \\
\hline Alouatta belzebul (Linnaeus, 1766) & Guariba & LT, RK, $\mathrm{OO}$ & - & - & VU \\
\hline Cebidae & & & & & \\
\hline Cebus apella (Linnaeus, 1758) & Macaco-prego & LT, RK, OO & - & - & LC \\
\hline Saguinus niger (É. Geoffroy, 1806) & Guaribinha & LT, RK, OO & - & - & VU \\
\hline Saimiri sciureus (Linnaeus, 1758) & Macaco-de- cheiro & LT, OO & - & - & LC \\
\hline Pitheciidae & & & & & \\
\hline Callicebus moloch (Hoffmannsegg, 1807) & Zogue-zogue & LT, RK & - & - & LC \\
\hline Chiropotes utahickae (Hershkovitz, 1985) & Cuxiú & LT & VU & VU & EN \\
\hline RODENTIA & & & & & \\
\hline Caviidae & & & & & \\
\hline Cuniculus paca (Linnaeus, 1758) & Paca & LT, CT, RK & - & - & LC \\
\hline Dasyprocta croconota* (Wagler, 1831) & Cutia & LT, CT, RK & - & - & - \\
\hline Dasyprocta prymnolopha (Linnaeus, 1841) & Cutia & CT, RK & - & - & $\mathrm{LC}$ \\
\hline Dasyprocta leporina (Linnaeus, 1758) & Cutia & 00 & - & - & \\
\hline Hydrochoerus hydrochaeris* (Linnaeus, 1766) & Capivara & 00 & - & - & $\mathrm{LC}$ \\
\hline Erethizontidae & & & & & \\
\hline Coendou prehensilis (Linnaeus, 1758) & Coandu & LT, RK, OO & - & - & LC \\
\hline Sciurinae & & & & & \\
\hline Guerlinguetus gilvigularis* (Wagner, 1842) & Quatipuru & LT, RK, $\mathrm{OO}$ & - & - & DD \\
\hline DIDELPHIMORPHIA & & & & & \\
\hline Didelphidae & & & & & \\
\hline Didelphis marsupialis Linnaeus, 1758 & Mucura & RK & - & - & LC \\
\hline
\end{tabular}


Acknowledgments: This study was possible with the help of the Instituto Chico Mendes de Conservação da Biodiversidade-ICMBio, the Universidade Federal Rural da Amazônia and the Vale Company. ASC, FMH, DG and FMD thank Vale for the research grants. HGB thanks CNPq, FAPERJ and Prociência/UERJ for the research and productivity grants. Dr. Leonardo dos Santos Ávilla, Dr. José Mauricio Barbanti Duarte, Dr. Gilson Evaristo Iack-Ximenes, Dr. Tadeu Gomes de Oliveira, Dra. Renata Leite Pitman, Dra. Liza Maria Veiga in memorian, Instituto Pró-Carnívoros in the name of Ricardo Luis Pires Boulhosa helped identify the species. We also thank the Vale staff who helped us in the field. This study is part of a masters thesis by A. S. Carvalho submitted to the Graduate Program in Ecology and Evolution of Universidade do Estado do Rio de Janeiro, in partial fulfillment of the requirements for the Master degree in Ecology and Evolution.

\section{Literature Cited}

Brasília. 2004. Portaria Ministério do Meio Ambiente no 126, de 27 de maio de 2004. Diário Oficial da União 28/05/2004.

Bonvicino, C.R., J.A. Oliveira and P.S. D'ándrea. 2008. Guia dos Roedores do Brasil com Chaves para Gêneros Baseadas em Caracteres Externos. Rio de Janeiro: Centro Pan-Americano de Febre Aftosa. 120 pp.

Borges, P.A.L. and W.M. Tomás. 2004. Guia de Rastros e Outros Vestígios de Mamíferos do Pantanal. Corumbá: Embrapa Pantanal. 148 pp.

Botelho, A.L.M., A.M. Calouro, L.H.M. Borges and W.A. Chaves. 2012. Large and medium-sized mammals of the Humaitá Forest Reserve, southwestern Amazonia, state of Acre, Brazil. Check List 8(6): 11901195.

Cleef, A. and M.F.F. Silva. 1994. Plant communities of the Serra dos Carajás (Pará), Brazil. Boletim Museu Paraense Emílio Goeldi, Série Botânica 10(2): 269-281.

Colwell, R.K. 2006. EstimateS 8.0.0. Statistical estimation of species richness and shared species from samples. Version 8. Accessible at purl.oclc.org/estimates.

Costa, P.L., Y.L.R. Leite, S.L. Mendes and A.D. Ditchfield. 2005. Conservação de Mamíferos no Brasil. Megadiversidade 1(1): 103-112.

Eisenberg, J.F. and K.H. Redford. 1999. Mammals of the Neotropics, The Central Neotropics: Ecuador, Peru, Bolivia, Brazil. $3^{\text {rd }}$ ed. Chicago: University of Chicago Press. 624 pp.

Iwanaga, S. 2004. Levantamento de Mamíferos Diurnos de Médio e Grande Porte no Parque Nacional do Jaú: Resultados Preliminares; pp. 195-210, in: S.R. Borges, S. Iwanaga, C.C. Durigan and M.R. Pinheiro (ed.). Janelas para a Biodiversidade no Parque Nacional do Jaú: uma estratégia para o estudo da biodiversidade na Amazônia. Manaus: Fundação Vitória Amazônica.

Haugaasen, T. and C.A. Peres. 2007. Vertebrate responses to fruit production in Amazonian flooded and unflooded forests. Biodiversity and Conservation 16(14): 4165-4190.

Lizcano, D. and S.J. Alvarez. 2008. Mazama rufina, in: IUCN 2010. IUCN Red List of Threatened Species. Version 2010.2. Accessible at http:// www.iucnredlist.org/. Captured on 03 August 2010.

Lopes, M.A. and S.F. Ferrari. 2000. Effects of Human Colonization on the Abundance and Diversity of Mammals in Eastern Brazilian Amazonia. Conservation Biology 14(6): 1658-1665.

Machado, A., G.M. Drummond and A.P. Paglia. 2008. Livro Vermelho da Fauna Brasileira Ameaçada de Extinção. Brasília: Ministério do Meio Ambiente. 1420 pp.

Mamede, S.B. and C.J.R. Alho. 2008. Impressões do Cerrado e Pantanal: Subsídios para a Observação de Mamíferos Silvestres não Voadores. $2^{\text {nd }}$ ed. Campo Grande: UFMS. 208 p.p
MMA (Ministério do Meio Ambiente). 2003. Lista de Animais Ameaçados de Extinção do Brasil. Accessible at http://www.mma.gov.br/port/ sbf/fauna/index.cfm/. Captured on 27 January 2010.

Paglia, A.P., G.A.B. Fonseca and J.M.C. Silva. 2008. A Fauna Brasileira Ameaçada de Extinção: Síntese Taxonômica e Geográfica; pp. 63-70, in: A. Machado, G.M. Drummond and A.P. Paglia (ed.). Livro Vermelho da Fauna Brasileira Ameaçada de Extinção. Brasília: Ministério do Meio Ambiente.

Patton, J.L., M.N.F. Silva and J.R. Malcolm, 2000. Mammals of the Rio Juruá and the Evolutionary and Ecological Diversification of Amazonia. Bulletin of the American Museum of Natural History 244: 003-306.

Porto, M. and M.F.F. Silva. 1989. Tipos de Vegetação Metalófila da Área da Serra dos Carajás e Minas Gerais. Acta Botânica Brasílica 3(2): 13-21.

Reis, N.F., A.L. Peracchi, W.A. Pedro and I.P. Lima. 2006. Mamíferos do Brasil. Londrina: Universidade Estadual de Londrina. 439 pp.

Santos, F.S. and A.C. Mendes-Oliveira. 2012. Diversity of medium and large sized mammals in the Urucu basin, Amazonas, Brazil. Biota Neotropica 12(3): 282-291.

Secco, R.S. and A.L. Mesquita. 1983. Nota Sobre a Vegetação de Canga da Serra Norte. I. Boletim do Museu Paraense Emílio Goeldi, Nova Série Botânica (59): 1-13.

SECTAM (Secretaria Executiva de Estado de Ciência, Tecnologia e Meio Ambiente). 2006. Relação das Espécies Ameaçadas do Estado do Pará. Accessible at http://www.sectam.pa.gov.br/. Captured on 19 November 2008.

Silva, M.F.F., N.L. Menezes, P.B. Cavalcante and C. Joly. 1986. Estudos Botânicos: Histórico, Atualidade e Perspectivas; pp. 184-207, in: J.M.G. Almeida (ed.). Carajás: Desafio Político, Ecologia e Desenvolvimento. São Paulo: Brasiliense/CNPq.

Silva, M.F.F., R.S. Secco and M.G.A. Lobo. 1996. Aspectos Ecológicos da Vegetação Rupestre da Serra dos Carajás (PA). Acta Amazônica 26(1/2): 17-44.

Silva, M.F.F. 1992. Distribuição de Metais Pesados na Vegetação Metalófila de Carajás. Acta Botânica Brasílica 6(1): 107-122.

Silva, J.M.C., A.B. Rylands and G.A.B. Fonseca. 2005. The Fate of the Amazonian Areas of Endemism. Conservation Biology 3(19): 689694.

Soares-Filho, B.S., D.C. Nepstad, L.M. Curran, G.C. Cerqueira, R.A. Garcia, C.A. Ramos, E. Voll, A. McDonald, P. Lefebvre and P. Schlesinger. 2006 Modelling Conservation in the Amazon Basin. Nature 440(7083): 520-523.

Toledo, P.M., H.M. Moraes-Santos, C.C.S. Melo. 1999. Levantamento Preliminar de Mamíferos não Voadores da Serra dos Carajás: Grupos Silvestres Recentes e Zooarqueológicos. Boletim Museu Paraense Emilio Goeldi, série Zoológica 15(2): 141-157.

Voss, R. and L.H. Emmons. 1996. Mammalian Diversity in Neotropical Lowland Rainforest: a Preliminary Assessment. Bulletin of the American Museum of Natural History 230: 1-115.

Wilson, D.E. and D.M. Reeder. 2005. Mammal Species of the World: A Taxonomic and Geographic Reference. $3^{\text {rd }}$ ed. Baltimore: Johns Hopkins University Press. 2142 pp.

RECEIVED: May 2011

ACCEPTED: November 2013

PUBLISHED ONLINE: February 2014

EDITORIAL RESPONSIBILITY: Maria Luisa Jorge 